\title{
Analgesic and anti-inflammatory activity of aqueous extract of Bubonium graveolens
}

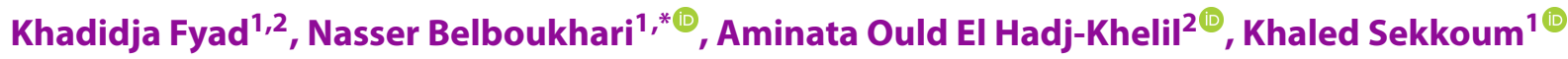

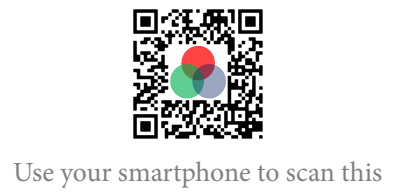

QR code and download this article

\begin{abstract}
Introduction: Bubonium graveolens is used in traditional pharmacopoeia against imbalances of the gastrointestinal tract, cephalic pains, and bronchitis, and as an anti-inflammatory agent. Methods: We have investigated the analgesic and anti-inflammatory activities of the aqueous extract of Bubonium graveolens in male mice of strain NMRI Albinos, weighing between $22 \mathrm{~g}$ and $38 \mathrm{~g}$. Acetic acid was used to induce writhes in the mice and inflammation of paw edema. Results: Evaluation of the analgesic activity showed that the aqueous extract at $150 \mathrm{mg} / \mathrm{kg}$ of the plant induced a decrease in the number of abdominal cramps caused by $1 \%$ acetic acid. The aqueous extract of the plant had an analgesic effect almost equal to that of Diclofenac; in fact, the latter caused a pain inhibition of $49 \pm 1.1 \%$ while Bubonium graveolens caused a pain inhibition of $49.6 \pm 2.1 \%$, at the concentration of $150 \mathrm{mg} / \mathrm{kg}$. Evaluation of the percentage of inhibition showed that the aqueous extract of Bubonium graveolens had a better anti-inflammatory activity compared to Diclofenac sodium during the treatment duration $(69.57 \%-56.52 \%$ at $60 \mathrm{~min} ; 71.43 \%-50.00 \%$ at $120 \mathrm{~min}$, and $75.00 \%-66.67 \%$ at $180 \mathrm{~min})$. Conclusion: The results of this research indicate that Bubonium graveolens inhibits inflammation and could explain its effective use in traditional medicine.

Key words: Bubonium graveolens, analgesic activity, aqueous extract essential oils
\end{abstract}

${ }^{1}$ Bioactive Molecules \& Chiral Separation Laboratory. Fac exact sciences, University Tahri Mohamed, Bechar 08000, Algeria

${ }^{2}$ Faculty of Nature and Life Sciences, University of Kasdi Merbah. Ouargla 30000, Algeria

Correspondence

Nasser Belboukhari, Bioactive Molecules \& Chiral Separation Laboratory. Fac exact sciences, University Tahri Mohamed, Bechar 08000, Algeria

Email: belboukhari.nasser@yahoo.com

History

- Received: Jul 21, 2020

- Accepted: Sep 18, 2020

- Published: Sep 30, 2020

DOI : 10.15419/bmrat.v7i9.632

\section{Check for updates}

\section{Copyright}

(c) Biomedpress. This is an openaccess article distributed under the terms of the Creative Commons Attribution 4.0 International license.

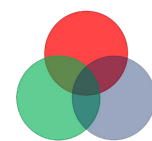

\section{INTRODUCTION}

Bubonium graveolens is a medicinal plant growing in arid and semi-arid climates. It stretches from the north of Africa to the desert of Central Asia but is widely represented in southwestern Algeria and southern Morocco ${ }^{1,2}$. It is considered as one of the most important Saharan plants, used specifically for its medicinal and aromatic properties ${ }^{3,4}$. It is known locally as 'Tafss' 1 .

Bubonium graveolens is used in the treatment of gastrointestinal disorders, fever, cephalic, dietary, and bronchitis, as well as an anti-inflammatory agent ${ }^{5-7}$. Recently it was used as a botanical fungicide ${ }^{8,9}$ and was reported to possess antimicrobial and hypoglycemic activities ${ }^{10,11}$.

According to literature review, a few studies have been done on these species and have shown this plant to be rich in monoterpenes ${ }^{12}$, flavonoids ${ }^{13}$, sesquiterpenes $^{14}$, and essential oils ( 43 compounds have been identified; the latter are present in the leaves and flowers $)^{1}$. The essential oils of Bubonium graveolens contain mainly oxygenated monoterpenes (37.6\% in leaves, and $60.3 \%$ in flowers), with 1,8 -cinoeole $(21.5 \%)$ as the main constituent in the flowers ${ }^{1}$. The other major components are cis-chrysanthenyl acetate $(44.30 \%)$, cis- 8 -acetoxychrysanthenyl acetate (33.70\%), and $\tau$-muurolol $(6.51 \%)^{15}$.
The aim of the study herein is to evaluate the pharmacological properties of the aqueous extract of Bubonium graveolens to provide a scientific basis for the empirical use of this plant in traditional pharmacopoeia. Therefore, justification of the potential use of Bubonium graveolens as an analgesic will be assessed and verified.

\section{MATERIALS - METHODS}

\section{Plant material}

Aerial parts of Bubonium graveolens were collected during flowering in south-western Algeria (March 2018), and identified by the National Agency of Nature Protection (ANN), Bechar, Algeria. Botanical identification and voucher specimen are conserved in the Medicinal Plant Encyclopedia Herbarium of bioactive molecules and Chiral Separation Laboratory (BMCS Lab) under accession number MPE11-7E3.

\section{Preparation of the extract}

The aqueous extract was prepared by Soxhlet extraction of 25 grams of powder in $150 \mathrm{~mL}$ of distilled water for 6 hours. After decantation, the supernatant was filtered and the filtrate was evaporated under vacuum in a rotary evaporator. An aqueous extract of various concentrations $(50 \mathrm{mg} / \mathrm{kg}, 100 \mathrm{mg} / \mathrm{kg}, 150 \mathrm{mg} / \mathrm{kg}$, 
$200 \mathrm{mg} / \mathrm{kg}, 750 \mathrm{mg} / \mathrm{kg}, 1000 \mathrm{mg} / \mathrm{kg}$, and $2000 \mathrm{mg} / \mathrm{kg}$ ) were prepared.

\section{Apparatus}

Plethysmometer (LE 7500 plethysmometer, Barcelona, SPAIN) was used for measuring the volume of the mouse paw.

\section{Reagents}

All chemicals were purchased from Sigma-Aldrich (St Louis, MO, USA).

\section{Animals}

Permission was obtained from the Committee of use of animal experiments (Approval \# 943-19). The study was carried out on mice NMRI Albinos, 100\% males, from the breeding laboratory of the Pasteur Institute of Algeria. Their weight was between 22 and $38 \mathrm{~g}$. Mice were randomly housed in plastic cages with controlled temperature $\left(25^{\circ} \mathrm{C}\right)$ and under a $12 \mathrm{~h}$ light-dark cycle. Animals benefited from an adaptation period before use. They were fed and maintained under standard procedures, with access to water and standard food (Bovin fattening). The mice were with an empty stomach for 17 hours before each experiment ${ }^{16}$.

\section{Toxicity test}

For toxicity testing, 8 batches of 6 mice were used for testing the aqueous extract of Bubonium graveolens. Doses administered were as follows: 50, 100, 150, 200, 750,1000 and $2000 \mathrm{mg} / \mathrm{kg}$ of the aqueous extract. They were administered with a physiological solution at the rate of $10 \mu \mathrm{l} / \mathrm{g}$ of mouse body weight; the control batch was administered with physiological water at a rate of $10 \mu \mathrm{l} / \mathrm{g}$.

The mice were respectively dosed intraperitoneally (IP) with aqueous extract or physiological water, based on body weight. They were then observed for 2 hours to record immediate signs and behavior following intoxication, and monitored against the control group. After the 2 hours, the mice were given food and water, followed by two observation periods (one for 24 hours and one for 48 hours).

\section{Study of analgesic activity \\ Test Writhing}

The method used is similar to that described by Koster et al. ${ }^{17}$. We studied analgesic activity in mice using a pain reaction, which is caused in mice by intraperitoneal (IP) injection of acetic acid $1 \%{ }^{18}$.

Five groups of six mices were constituted:
Control batch: The mice of this batch receive physiological saline 30 minutes before the injection of acetic acid (1\%) by IP according to body weight.

Batch reference: The animals of this batch were treated by subcutaneous injection (SC) of Diclofenac sodium, at 30 minutes before the IP injection of acetic acid (1\%).

Test batch: The animals receive IP administration of the extracts at these concentrations $(50 \mathrm{mg} / \mathrm{kg}, 100$ $\mathrm{mg} / \mathrm{kg}, 150 \mathrm{mg} / \mathrm{kg}, 175 \mathrm{mg} / \mathrm{kg}$ ), at 30 minutes before the injection of acetic acid (1\%), according to body weight.

Five minutes after the injection of acetic acid, we counted the number of cramps in each mouse for 20 minutes. The percentage of inhibition of the tested products was evaluated by the determination of the mean of cramps, calculated according to the formula:

$$
\% \text { inhibition }=\frac{\mathrm{A}-\mathrm{B}}{\mathrm{A}} \times 100
$$

A: represents the average cramp of the mice of the control group.

B: represents the mean cramps of the mice of the treated lots.

\section{Anti-Inflammatory activity}

The anti-inflammatory activity study was evaluated by the method of inhibition of $1 \%$ formalin-induced mouse paw edema. The mice before each experiment were with an empty stomach for 17 hours, at which time inflammation is induced by injecting formalin into the plantar arch of the left mouse paw ${ }^{19}$.

Measurements of the volumes of the right hind paw of each mouse were performed prior to induction of edema and every $1 \mathrm{~h}, 2 \mathrm{~h}, 3 \mathrm{~h}, 4 \mathrm{~h}$ and $5 \mathrm{~h}$ after the formalin injection. Half an hour before the formalin injection, the different lots of mice received the different treatments:

A control group of 6 mice treated IP with physiological water, according to body weight.

A reference batch of 6 mice treated by IP with $\mathrm{Di}$ clofenac sodium $(20 \mu \mathrm{l})$.

A batch of 6 mice treated with the extract IP with the plant extract Bubonium graveolens at a dose of 150 $\mathrm{mg} / \mathrm{kg}$, according to body weight.

The anti-inflammatory activity of the products was tested and its evolution was estimated by the determination of the average percentages of inhibition of the edema, calculated according to the formula:

$$
\begin{aligned}
& \% \mathrm{~d}^{\prime} \text { inhibition }= \\
& \frac{(\mathrm{Vt}-\mathrm{V} 0) \text { temoin }-(\mathrm{Vt}-\mathrm{V} 0) \text { traite }}{(\mathrm{Vt}-\mathrm{V} 0) \text { temoin }} \times 100
\end{aligned}
$$

$\mathrm{V}_{0}$ : represents the volume of the paw at $\mathrm{t}=0$ (before injection of formalin).

$\mathrm{V}_{t}$ : represents the volume of the paw at any time $\mathrm{t}$. 


\section{Statistical analysis}

The obtained results were subjected to an analysis of the variance (ANOVA) at a probability level of $\mathrm{P}<$ 0.05 , and $(n)$ represents the number of mice in each group.

\section{RESULTS}

\section{Toxicity}

Immediate signs of change, intoxication, and sudden death (in comparison with control animals) were followed for 2 hours after IP administration of the aqueous extract. At $24 \mathrm{~h}$ and then $48 \mathrm{~h}$ later, we again observed the mice to determine the delayed effects of taking different doses of the aqueous extract of Bubonium graveolens. Intra-peritoneal administration causes changes in the physical activity and behavior of the mice. Table 1 summarizes the immediate signs recorded during this experiment.

The observed results show that doses of 50 to 150 $\mathrm{mg} / \mathrm{kg}$ did not cause any noticeable change in the behavior or activity of the mice. On the other hand, it should be noted that the animals receiving doses of 200, 750, 1000 and $2000 \mathrm{mg} / \mathrm{kg}$ showed strong signs of hypo-activity, drowsiness and tachycardia, with no mortality for the duration of study.

\section{Writhing test}

The acetic acid induced writhing test is a simple and commonly used method for screening analgesic drugs. The administration of acetic acid is responsible for the release of endogenous substances which are supposed to excite the nerve endings, thereby causing the pain ${ }^{20}$.

The following table (Table 2) gives us a representation of the analgesic activity of the aqueous extract of Bubonium graveolens.

The control group which received physiological saline showed writhing after the intraperitoneal injection of $1 \%$ acetic acid; the average number of abdominal contractions were $121 \pm 0.7$, with a percentage inhibition of $0 \%$ over a duration of 20 minutes.

Subcutaneous administration of Diclofenac sodium (20 $\mu \mathrm{l})$ followed by injection of acetic acid yielded an average number of abdominal contractions of $49 \pm$ 1.1 , which was equivalent to a percentage inhibition of $59.50 \%(\mathrm{p}<0.05, \mathrm{n}=5)$.

Administration by IP route of the aqueous extract of Bubonium graveolens in progressive doses (i.e. 50, $100,175 \mathrm{mg} / \mathrm{kg}$ ) yielded the following results: for 50 $\mathrm{mg} / \mathrm{kg}$ dose, the mean number of abdominal contractions was $108.8 \pm 0.4$, i.e. percentage of inhibition of
$10.08 \%$; for $100 \mathrm{mg} / \mathrm{kg}$ dose, the mean number of abdominal contractions was $67 \pm 2.1$, i.e. percentage inhibition of $44.62 \%$; for $175 \mathrm{mg} / \mathrm{kg}$ dose, the mean number of abdominal contractions was $54.6 \pm 1$, i.e. percentage of inhibition was $54.87 \%(\mathrm{p}<0.05, \mathrm{n}=5)$ (Table 2 and Figure 1).

\section{Evaluation of anti-inflammatory activity}

Assessment of the anti-inflammatory activity of the aqueous extract was carried out by measuring the volume of edema induced by formalin in three lots of 6 mice (control, test and reference). The results are represented in the form of a curve showing the evolution of the volume of the edema as a function of time (Figure 3). The injection of formalin at the hind paw of the mice causes a progressive increase of the edema with a maximal volume after 3 hours ${ }^{21}$. Formalin causes local inflammation when injected into the fascia of the sole of the foot ${ }^{22}$ as well as carrageenan ${ }^{23}$. Intraperitoneal administration of Diclofenac sodium at $20 \mu \mathrm{l}$ prevents the increase in the volume of the mouse paw. Indeed, mouse paw volume after $30 \mathrm{~min}$ was $0.073 \pm 0.019$, after $60 \mathrm{~min}$ was $0.067 \pm 0.020$, after $120 \mathrm{~min}$ was $0.062 \pm 0.016$, and after $180 \mathrm{~min}$ was $0.050 \pm 0.003$.

The dose of $150 \mathrm{mg} / \mathrm{kg}$ of the aqueous extract of Bubonium graveolens, administered IP, importantly prevented the inflammatory process. Indeed, the increase in the volume of the mouse paw was $0.075 \pm$ $0.031,0.060 \pm 0.052,0.055 \pm 0.036$, and $0.053 \pm 0.022$ after 30, 60, 120, and $180 \mathrm{~min}$, respectively.

The following figure gives a representation of the percent inhibition of mouse left leg edema induced by formalin (1\%) and after administration of the aqueous extract of Bubonium graveolens and Diclofenac.

The anti-inflammatory effect of the aqueous extract of Bubonium graveolens has been evaluated in the present work. The results obtained show that the aqueous extract has an anti-inflammatory activity significant to that of Diclofenac sodium.

The results obtained from the anti-inflammatory tests show that the aqueous extracts of Bubonium graveolens in our study appreciably reduce formalininduced edema.

\section{DISCUSSION}

The results of the evaluation of the analgesic activity allowed us to note that the control mice developed a large number of cramps (121 cramps for 20 minutes) after administration of acetic acid. The mice that were treated with Diclofenac developed a reduced number of cramps compared to the control group; this 


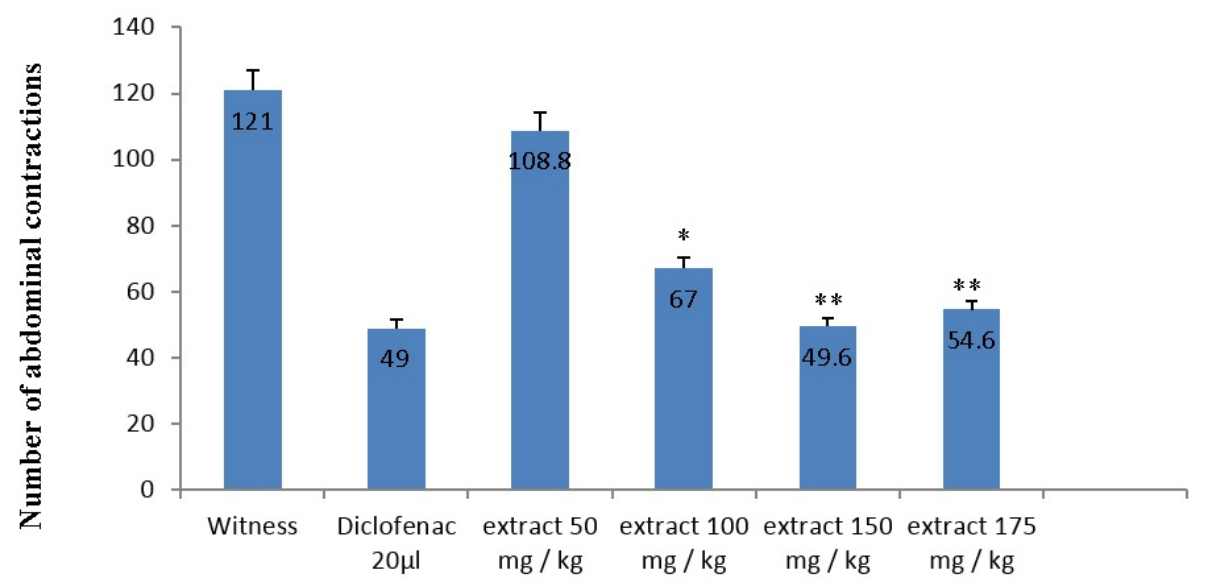

Figure 1: Effects of aqueous extract of Bubonium graveolens on pain induced by acetic acid $1 \%$. Each value represents the average of the number of abdominal contractions; ${ }^{*}: p<0.05,{ }^{* *}: p<0.01$, significant difference from the negative control group, with $\mathrm{n}=5$. $^{a}$

${ }^{a}\left({ }^{*}, * *,{ }^{* * *}\right)$ Describe respectively that $\mathrm{p}<0.05, \mathrm{p}<0.01$ and $\mathrm{p}<0.001$; Comparison to the corresponding controls (ANOVA).

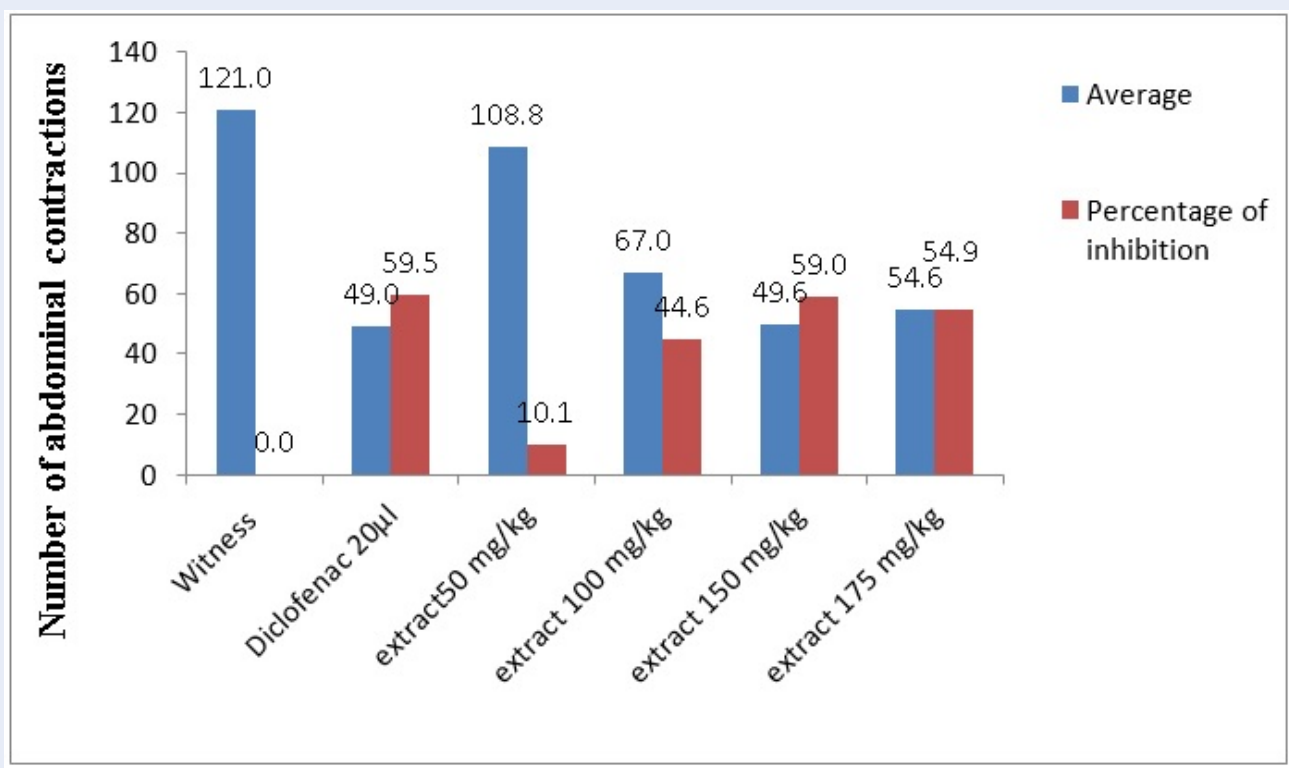

Figure 2: Effects of aqueous extract of Bubonium graveolens on pain induced by acetic acid 1\%. Each value represents the average and percentage of inhibition of abdominal contractions. 
Table 1: Results of the intraperitoneal toxicity test of the aqueous extract of Bubonium graveolens

\begin{tabular}{|c|c|c|c|c|c|}
\hline \multirow[t]{2}{*}{ Product } & \multirow[t]{2}{*}{ Doses (mg/kg) } & \multicolumn{3}{|c|}{ Symptoms } & \multirow[t]{2}{*}{ Mortality } \\
\hline & & Hypoactivity & Drowsiness & Tachycardia & \\
\hline \multirow{8}{*}{$\begin{array}{l}\text { Aqueous } \\
\text { extract }\end{array}$} & 50 & - & - & - & 0 \\
\hline & 100 & - & - & - & 0 \\
\hline & 150 & - & - & - & 0 \\
\hline & 200 & + & + & + & 0 \\
\hline & 750 & ++ & ++ & ++ & 0 \\
\hline & 1000 & +++ & +++ & +++ & 0 \\
\hline & 2000 & +++ & +++ & +++ & 0 \\
\hline & & & & & ; + :High sign \\
\hline
\end{tabular}

Table 2: Analgesic effect of the aqueous extract of Bubonium graveolens on the abdominal contractions induced in the mouse by the injection of acetic acid

\begin{tabular}{ccc}
\hline Organs and doses $(\mathbf{m g} / \mathbf{k g})$ & $\begin{array}{c}\text { Number of abdominal } \\
\text { contractions }\end{array}$ & Percent inhibition (\%) \\
Witness & $121 \pm 0.7$ & 59.50 \\
Diclofenac $(20 \mu \mathrm{l})$ & $49 \pm 1.1$ & \\
& Excerpts & 10.08 \\
50 & $108.8 \pm 0.4$ & 44.62 \\
100 & $67 \pm 2.1$ & 59.00 \\
175 & $49.6 \pm 2.1$ & 54.87 \\
\hline
\end{tabular}

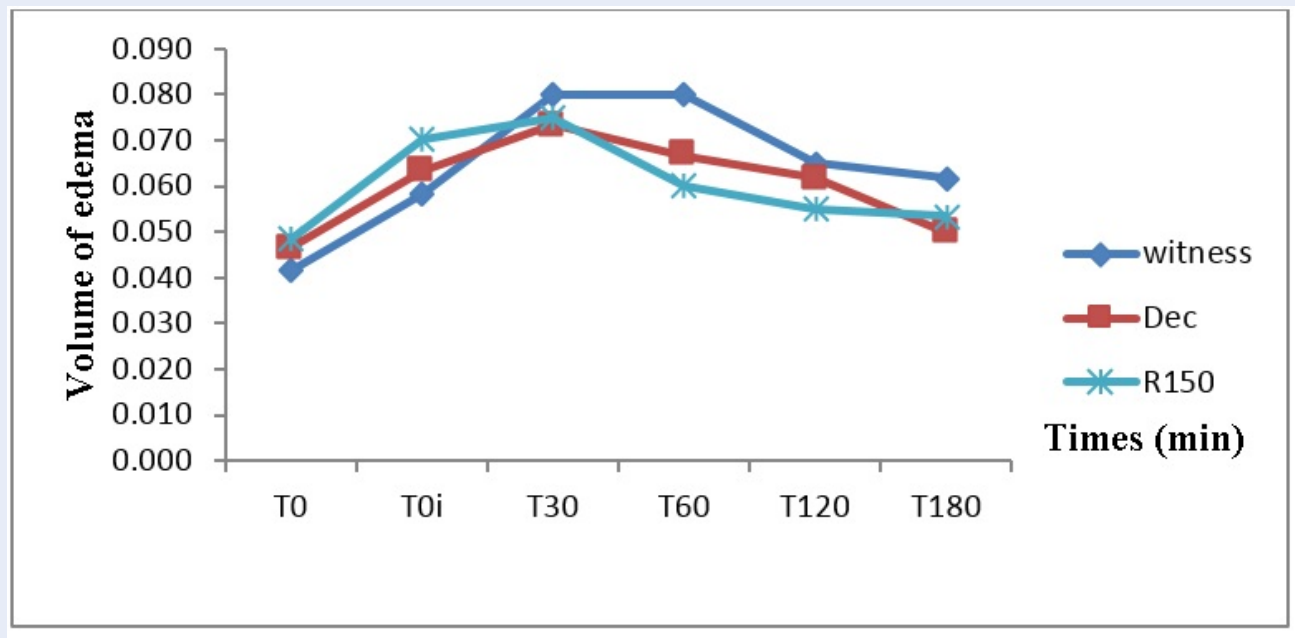

Figure 3: Evolution of edema in the presence of an intraperitoneal pretreatment, after administration of the aqueous extract $150 \mathbf{~ m g} / \mathbf{~ k g}$. Each point represents an average of 6 mice $(n=6)$. 


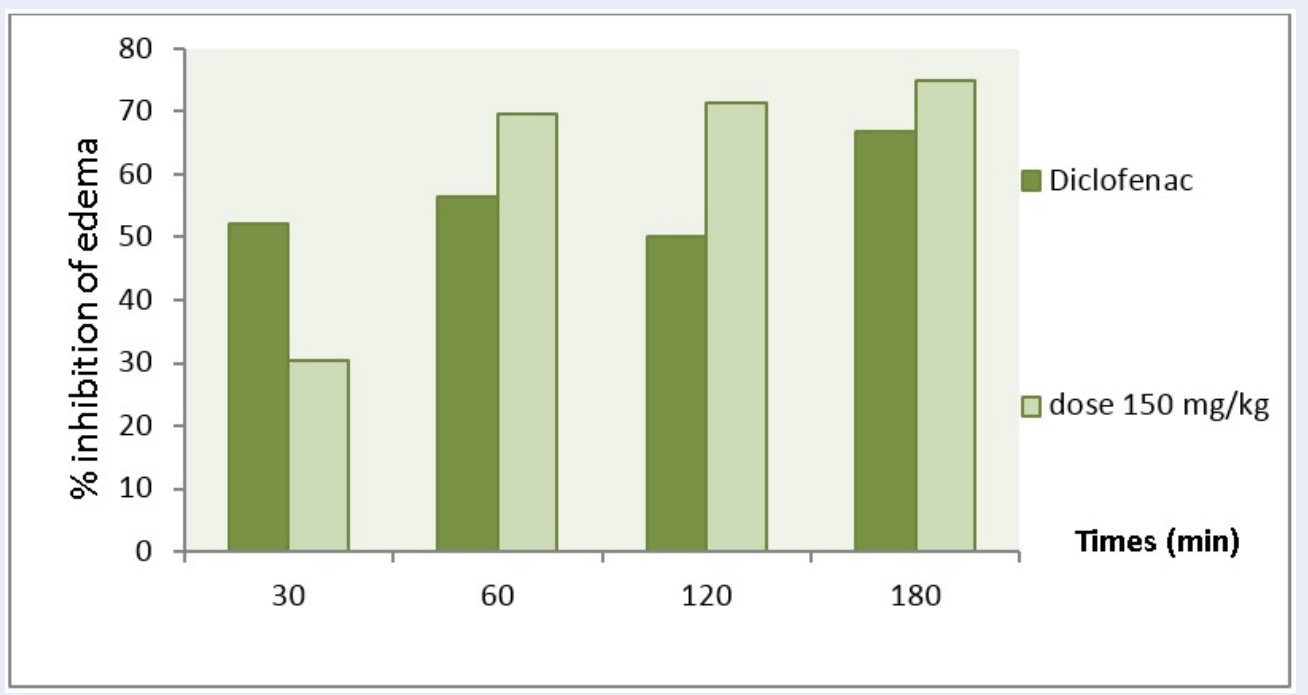

Figure 4: Percentage of inhibition of left paw edema of mice, induced by formalin (1\%) and after the administration of the aqueous extract of Bubonium graveolens and diclofinac.

was confirmed by the observed percentage of protection (59.5\% inhibition). Conversely, mice that were treated with our extract developed a reduced number of cramps compared to the control mice. In fact, the percentages of protection against cramps calculated for the different products show a relative superiority of the Bubonium graveolens extract, namely for 150 $\mathrm{mg} / \mathrm{kg}$ dose (59\% inhibition), followed by $175 \mathrm{mg} / \mathrm{kg}$ dose (54\% inhibition), and $100 \mathrm{mg} / \mathrm{kg}$ dose (44\% inhibition). The results obtained from the analgesic test show that our aqueous extract appreciably reduces the number of abdominal contractions induced by acetic acid. The number of abdominal contractions is comparable to that of Diclofenac. This shows that our plant has a very robust analgesic activity.

For the study of the biological activities of the extracts of Bubonium graveolens, we reviewed the existing scientific literature on this plant. Phytochemical studies were carried out on the different parts of our plant. These studies made it possible to characterize the presence of flavonoids + , saponosides ++ , tannins + , steroids + , unsaturated sterols +++ , terpenes +++ , and cardenolides $+{ }^{24}$. The richness of the aqueous extract of our plant in terms of the different chemical constituents contribute to its analgesic activity.

Our goal was to find an anti-inflammatory agent and this goal was reached. Unfortunately, we were not able to determine the structure of these compounds.

Significant results obtained during this study of the aqueous extract of Bubonium graveolens demonstrated remarkable analgesic properties. These results constitute a scientific basis that justifies the traditional use of Bubonium graveolens in the management of pathologies with an inflammatory component.

\section{CONCLUSION}

The anti-inflammatory effect of aqueous extracts of Bubonium graveolens at a dose of $150 \mathrm{mg} / \mathrm{kg}$ has been evaluated in the present study. The results obtained show that the aqueous extract has an anti-inflammatory activity significant to that of $\mathrm{Di}$ clofenac sodium. The results obtained from the antiinflammatory tests show that our aqueous extract of Bubonium graveolens appreciably reduce formalininduced edema.

The analgesic activity of the aqueous extract of Bubonium graveolens at a dose of $150 \mathrm{mg} / \mathrm{kg}$ caused a percentage of inhibition very near to that of Diclofenac (49\% and $49.60 \%$, respectively). The aqueous extract of Bubonium graveolens show an anti-inflammatory activity in the test of edema. In conclusion, the results of the present study provide evidence for the anti-inflammatory and analgesic activities of Bubonium graveolens growing in Algeria, and could explain the benefits of the traditional use of this plant.

\section{ABBREVIATIONS}

IP: intraperitoneal

NMRI: Naval Medical Research Institute

SC: subcutaneeous

$\mu \mathbf{m}$ : Microliter 


\section{ACKNOWLEDGMENTS}

The authors are grateful to Mr A. Benabdelhakem (expert botanist, ANN, Bechar) for the identification of plant.

\section{AUTHOR'S CONTRIBUTIONS}

FK and AOEK (Co director of project): performed the significant contributions to conceptualization and design; and the acquisition, analysis, and interpretation of the data. BN and SK: performed the drafting of the article and critical revision for important intellectual content. All the authors approved the final version of the manuscript to be published.

\section{FUNDING}

This work is supported by the General Direction of Scientific Research of Algeria (DGRSDT) as part of Research project (PRFU) $\mathrm{N}^{\circ}$ : B00L01UN080120190002.

\section{AVAILABILITY OF DATA AND MATERIALS}

Data and materials used and/or analyzed during the current study are available from the corresponding author on reasonable request.

\section{ETHICS APPROVAL AND CONSENT TO PARTICIPATE}

Not applicable.

\section{CONSENT FOR PUBLICATION}

Not applicable.

\section{COMPETING INTERESTS}

The authors declare that they have no competing interests.

\section{REFERENCES}

1. Cheriti A, Saad A, Belboukhari N, Ghezali S. The essential oil composition of Bubonium graveolens (Forssk) maire from the Algerian Sahara. J Flavour and Fragrance. 2007;22:286-288. Available from: https://doi.org/10.1002/ffj.1794.

2. Aici D, Cheriti A, Bourmita Y, Belboukhari N. Antimicrobial activity of essential oils of Bubonium graveolens (forssk.) and Anvillea radiata (coss.). Phyto Chem Bio Sub J. 2013;7:116119.

3. Znini M, Cristofari G, Majidi L, Ansari A, Bouyanzer A, Paolini J, et al. Green approach to corrosion inhibition of mild steel by essential oil leaves of Asteriscus graveolens (Forssk.) in sulphuric acid medium. Int J Electrochem Sci. 2012;7:3959-3981.

4. Said ME, Bombarda I, Naubron JV, Vanloot $P$, Jean M, Cheriti $A$, et al. Isolation of the major chiral compounds from Bubonium graveolens essential oil by HPLC and absolute configuration determination by VCD. Chirality. 2017;29:70-79. PMID: 28019704. Available from: https://doi.org/10.1002/chir.22672.

5. Messaoudi R, cheriti A, bourmita Y. Bioassay-guided isolation of the major compound with antioxidant activity from the algerian medicinal plant bubonium graveolens. J Asian J Pharm
Clin Res. 2018;11:424-426. Available from: https://doi.org/10. 22159/ajpcr.2018.v11i11.28514.

6. Melekmi N, Saad A, Belboukhari N, Cheriti A. Antimicrobial activity of the essential oil of Bubonium graveolens. Annales de I'université de Bechar. 2006;2:22-26.

7. Boulenouar N, Marouf A, Cheriti A, Belboukhari N. Medicinal plants extracts as source of antifungal agents against Fusarium oxysporum f. Sp. Albedinis. J Agr Sci Tech. 2012;14:659669.

8. Mebarki L, kaid harche $M$, benlarbi, kasmi $H$, Matrouine $M$. Bubonium graveolens extracts for controlling Fusarium oxysporum f. sp. albedinis. J Romanian Biotechnological Letters. 2015;20:10026-10035.

9. Akssira M, Mellouki F, Salhi A, Alilou $H$, Saouf A, Hanbali $F$ et al. Naupliolide, a sesquiterpene lactone with a novel tetracyclic skeleton from Nauplius graveolens subsp. : Odorus, Tetrahedron Lett. 2006;47:6719-6721. Available from: https: //doi.org/10.1016/j.tetlet.2006.07.094.

10. Ramadane F, Belboukhari N, Cheriti A, Zaouani M. Evaluation de la toxicité de deux Astéraceae du Sahara Algérien launaea arbonescens et Bubonium gravoelens. Annales de l'université de Béchar;200(4):1112-6604.

11. Ramdane F, Essid R, Mkadmini K, Hammami M, Fares N, Mahammed $\mathrm{MH}$, et al. Phytochemical composition and biological activities of Astericus graveolens (Forssk) extracts. J Process Biochem. 2017;56:186-192. Available from: https://doi. org/10.1016/j.procbio.2017.03.004.

12. Chaib F, Allali H, Bennaceur M, Flamini G. Chemical composition and antimicrobial activity of essential oils from the aerial parts of Asteriscus graveolens (Forssk.) less. And Pulicaria incise (Lam.) DC: Two Asteraceae herbs growing wild in the Hoggar. J Chem Biodiver. 2017;14:1700092. PMID: 28467692. Available from: https://doi.org/10.1002/cbdv.201700092.

13. Ahmed AA, Ishak MS, Micheal HN, El-Ansari MA, El-Sissi H. Flavonoids of Asteriscus graveolens. J Nat Prod. 1991;54:1092-1093. Available from: https://doi.org/10.1021/ np50076a027.

14. Triana J, Eiroa JL, Morales M, Perez FJ, Brouard I, Quintana J, et al. Sesquiterpenoids isolated from two species of the Asteriscus alliance. J Nat Prod. 2016;79:1292-1297. PMID: 27145162. Available from: https://doi.org/10.1021/acs. jnatprod.5b01013.

15. Aouissi H, Gourine N, Wang H Xiaochun C, Bombardal Boudjeniba $M$, Yousf M. Chemical composition, antioxidative, antimicrobial and anti-cancer activities of Asteriscus graveolens (Forssk) essential oil. J Oriental Pharmacy and Experimental Medicine. 2018;18:135-142. Available from: https://doi.org/ 10.1007/s13596-018-0315-0.

16. Ouédraogo $\mathrm{N}$, et al. Etude des activités anti-inflammatoire, analgésique et antipyrétique des décoctés aqueux des feuilles et des racines de Pterocarpus erinaceus Poir. (Fabaceae). J Phytothérapie. 2012;10:286-292. Available from: https://doi. org/10.1007/s10298-012-0732-z.

17. Koster R, Anderson M, Beer EJ. Acetic acid for analgesic screening. Fed Proc. 1959;18:412-417.

18. Rahmani S, Belboukhari N, Sekkoum K, Cheriti A. Evaluation de I'activité anti-inflammatoire d'extraits aqueux de feuilles limoniastrum feei (plumbaginacea). J Algerian journal of arid environment. 2016;1:80-86.

19. Winter CA, Risley EA, Nuss GW. Carrageenan-induced edema in hind paw of the rat as an assay for anti-inflammatory drugs. Proc Soc Exp Biol Med. 1962;111:544-547. PMID: 14001233. Available from: https://doi.org/10.3181/00379727-111-27849.

20. Nirmal SM, Abdur R, Mohammad AA. Analgesic and Antipyretic Activities of Methanol Extract and Its Fraction from the Root of Schoenoplectus grossus. J Evid Based Complement Alternat Med. 2016;2016:3820704. PMID: 26977173. Available from: https://doi.org/10.1155/2016/3820704.

21. Singla AK, Pathak K. Topical antiinflammatory effects of Euphorbia prostrata on carrageenan-induced footpad oedema in mice. Journal of Ethnopharmacology. 1990;29:291-294. 
Available from: https://doi.org/10.1016/0378-8741(90)90040$\mathrm{Z}$.

22. Sen T, Nag CAK. Antiinflammatory evaluation of Pluchea indica root extract. J of Ethnopharmacology. 1991;33:135-141. Available from: https://doi.org/10.1016/0378-8741(91)90172A.

23. Ossipov $\mathrm{MH}$, Kovelowski C, Porreca F. The increase in morphine antinoceptive potency produced by carrageenan- induced hindpaw inflammation is blocked by nalttrindole, a selective delta-opiod antagonist. Neuroscience Letter. 1995;184:173-176. Available from: https://doi.org/10.1016/ 0304-3940(94)11199-S.

24. Haddouchi F, Chaouche TM, Halla N. Screening phytochimique, activités antioxydantes et pouvoir hémolytique de quatre plantes sahariennes d'Algérie. Phytothérapie. 2016;14:19. Available from: https://doi.org/10.1007/s10298-016-1086-8. 